\title{
Practice and Exploration of Collaboratively Promoting Curriculum Ideological and Political Construction in Higher Vocational Colleges
}

\author{
Junjun Song1, Jinfeng Li² \\ ${ }^{1}$ School of Information Engineering, Sichuan Post and Telecommunication College, Chengdu, China \\ ${ }^{2}$ First Primary School in Tongchuan District, Dazhou, China \\ Email: Songjj999999@163.com
}

How to cite this paper: Song, J.J. and Li, J.F. (2022) Practice and Exploration of Collaboratively Promoting Curriculum Ideological and Political Construction in Higher Vocational Colleges. Open Access Library Journal, 9: e8486.

https://doi.org/10.4236/oalib.1108486

Received: February 15, 2022

Accepted: March 6, 2022

Published: March 9, 2022

Copyright $\odot 2022$ by author(s) and Open Access Library Inc.

This work is licensed under the Creative Commons Attribution International License (CC BY 4.0).

http://creativecommons.org/licenses/by/4.0/

\begin{abstract}
At present, some effective exploration and practical results have been initially achieved in the construction of curriculum ideological and political collaborative education in higher vocational colleges, but there are still some problems that make higher vocational colleges in the process of promoting curriculum ideological and political education in trouble. There are various types of teacher collaboration, management mechanism, curriculum system construction and so on. Therefore, how to explore in terms of system construction, team training, and teaching and educating systems is an important guarantee for promoting the effectiveness of collaborative ideological and political education. In addition, the construction of a new era curriculum ideological and political collaborative education mechanism to achieve a multi-party collaborative development model plays a key role in the formation of the "three comprehensive education" and "big ideological and political" pattern.
\end{abstract}

\section{Subject Areas \\ Politics, Education}

\section{Keywords}

Higher Vocational Colleges, Curriculum Ideology and Politics, Practical Exploration

\section{1. 引言}

当前, 课程思政已然成为一种新的教育理念和研究热点, 不同学者对其 
内涵阐释也不尽相同。本质上课程思政是要求思政教育覆盖整个教育过程中, 是指通过课程教育教学过程中, 充分尊重学科特性和内在规律, 将课程本身 涵盖的思想政治元素挖掘出来, 有效融入到课程教学和改革的方方面面。课 程思政的本质应该是一种教育, 是为了立德树人。基于此, 高职院校所有课 程都可以作为培养学生多元化、全面发展的载体, 以课程作为载体和途径, 在育人过程中, 就要强调多方协同作用, 共同培育出符合国家需要的人才 $[1]$ 。 其中，高职院校协同推进的关键在于将作为子系统的思政老师、辅导员、专 业课老师、企业导师产生有效关联，协同关系，促进课程思政育人系统整体 效应提升。

习近平主席在全国高职院校思想政治工作会议上提出 “要坚持把立德树 人作为中心环节，把思想政治工作贯穿教育教学全过程，实现全程育人、全 方位育人，努力开创我国高等教育事业发展新局面”。

（一）高职院校协同推进课程思政建设理论依据

目前，高职院校思想政治教育工作逐步陷入了 “孤岛化” 的境地，也就 是思想政治工作几乎由思政老师承担，而忽视了其他各类课程的思政育人元 素和其他老师的育人责任。高职院校的思想政治理论课程虽然为必修课, 但 是效果甚微。新时代下, 党和国家针对这种情况对实行政治理论课提出了新 要求。无论是 2020 年 5 月教育部印发的《高等学校课程思想建设指导纲要》, 还是 2020 年 9 月习近平总书记在《思政课是落实立德树人根本任务的关键课 程》中，都着重强调了思政课程要与其他课程进行融合，形成协同育人效应。 2021 年 1 月教育部关于印发《新时代学校思想政治理论课改革创新实施方法》 的通知中, 提出要建立课程之间密切配合、必修和选修课程的相互协调的课 程体系，从而有效实现联动 $[2]$ 。国家、省市、以及相关部门出台有关课程思 政的政策文件，充分说明了国家对政治理论课程育人的重要性。

“协同理论” 最早是由德国学者哈肯提出的，协同理论认为 “各自系统 千差万别, 如激光中的原子、光子, 生物系统中的动物、植物, 社会系统中 的工厂、农村、团体、个人，他们的性质完全不同，但他们从无序向有序转 变的机制却是类似的，甚至是相同的，遵循共同的规律”。哈肯阐释道: “我 们现在好像在大山脚下，从不同的两边挖一条隧道，这个大山至今把不同的 学科分隔开来, 尤其是把软科学和应用科学分隔开来。” 同样, 在高职院校 课程思政这一系统中，思政教师、辅导员、专业课教师、企业导师构成了四 个子系统, 如何使他们打破传统的教学模式和壁垒, 形成内发性的组织构建 有效的课程思政育人机制, 进而更好地落实高职院校立德树人根本任务, 是 当前高职院校多方推进课程思政合作中的关键性问题。哈肯学者提出的协同 理论在这方面提供了一定的理论基础，从理论上看，高职院校课程思政育人 机制的构建应当视为整体，处理好构成高职院校课程思政育人中重要的几方 力量之间的关系，更有利于推进课程思政的改革和发挥育人效果。

（二）高职院校协同推进课程思政建设现实依据

此外, 大学生是作为我国发展进步的后发力量, 大学生的价值观正确引 导更是重中之重。高职院校应当抓住大学的课程特点和学生价值观进行融合 教育。处于大学阶段的学生正当价值认识提升与健全时期, 较容易受到外界 
的负面影响而模糊自身的判断力, 不利于形成正确、坚定的政治信仰。有些 学生对未来没有规划, 缺乏积极进取的精神和脚踏实地的行动, 对于国家人 民没有正确的认识, 这些对于国家对青年的期望目标有偏差。青年学生的培 养是利于党和国家长期发展的, 因此高职院校多方主题共同努力, 协同育人 势在必行。

\section{2. 高职院校协同推进课程思政建设实践经验}

以往高校教育过程中习惯性将思政教育单独派分给思政课程中, 将知识、 技能和思政教育剥离分开了，尤其是高职院校更强调课程中技能应用能力的 培养，容易将专业课教育和思政教育从课程体系中脱离出来，这是不利于高 技能、高水平人才培养体系的构建的。近年来，国内很多高校结合自身院校 特点, 积极探索课程思政协同育人的路径并逐步形成了自己的特色。譬如, 北京市、上海市的课程思政机制不是一成不变, 而是动态调整、不断摸索改 良的机制。北京市教育系统关心下一代委员会在学习贯彻习近平总书记关于 学校思想政治教育理论课的重要讲话后, 举办了一系列针对思政课教学的培 训班并积极开展高校思政课程的经验交流分享会，同时还在具体实践中结合 现实情况加强课程思政机制的构建。上海市更是从 2005 年以来至今，十几年 间对课程思政育人机制进行不断的发展和调整, 致力于将大中小学的德育课 程和思政课程进行一体化建设，其课程思政育人机制可分为三大阶段。第一 阶段实将教学目标中的德育育人元素融入到大中小学不同阶段不同学科的课 程之中的 “学科德育” ; 第二阶段是大中小学德育课程坚持 “两纲教育” 为 基础, 进行纵向衔接、横向贯通和主体关联的文化育人和实践育人教学，从 而有效提升课程思政改革的整体性; 第三个阶段是构建出了完善的课程思政 育人机制的制度体系，把 “立德树人” 作为教育的根本目的，形成了较为完 善的上海大中小学课程思政育人机制。

此外，全国各地许多高校也贡献了较为成熟的课程思政建设的经验。比 如, 作为综合性大学的复旦大学, 将工科类专业的代表课程中有机物质的提 取与制作和当代以屠呦呦为代表的科学家的对有机化学的贡献相结合并融入 到课堂教学。主动用真切的爱国精神感染学生, 不单单是对工科课程的教学, 而是将课程中的化学元素与爱国情怀相结合, 并激发学生热爱科学、热爱祖 国之情。通过从课程中挖掘出的具有说服力和感染力的思想政治元素来教育 学生主动肩负起建设祖国、推动科学发展的使命。还有, 北京联合大学在表 演理论课程教学中, 教师以生活与艺术的关系为抓手, 循循善诱, 引发学生 对于生活、思想与技术三者关系的思考。通过课程教育后, 学生发现到了表 演学习中思想与技巧同等重要, 自身在各个方面都有不断提升进步才能成长 成才。与此同时, 该校还创新性地举办各种竞赛活动, 培训活动等, 不仅激 发学生, 而且让更多教师在教学过程中不断思考、不断提升, 真正将课程思 政建设落到课堂教学之中 [3]。全国各地还有很多高校在课程思政育人机制建 设中贡献突出，在此不一一列举。通过对典型地区高校构建课程思政协同育 人过程中, 可以看到高校大多是采取试点的方式, 充分结合自身课程体系特 色, 选择部分课程进行试点探索, 取得一定的成效后再继续深入推进、发展, 
以此逐步形成完整的课程思政体系, 发挥课程的育人功能。在推进课程思政 建设过程中尤其是实践中, 师生参与的积极性是关键。其中, 思政教师、辅 导员、专业课教师、企业导师作为教师群体更是机制运行的核心力量。高校, 尤其是高职院校, 企业导师是引导学生从学校到社会实践的教育者、指路人。 高职院校在协同推进课程思政建设时, 非常注重这几个子系统的功能性, 确 定了相应的制度来保障课程思政建设的有效推进。比如, 明确将课程思政建 设的要求纳入教学大纲, 这是对专业课教师的要求; 依托思政课程的教学平 台, 放入更多思政元素, 这是对思政教师的要求; 学生活动中, 日常教育中 有机融入思政教育, 这是对辅导员的要求; 同时, 对企业导师的要求体现在 企业导师聘任和评价中。最后, 高职院校更多是结合区域特点和自身特点来 进行课程的选择。四个子系统的协同是从教学角度激励教师不断提高课程思 政的教学能力。高校只有率先在课程思政建设中, 不断丰富课程思政教学内 容、方式才能更好激发出学生的学习兴趣, 培养学生全面发展。

\section{3. 高职院校协同推进课程思政建设框架}

目前, 课程思政协同育人建设过程中初步取得一定的成效, 但是还有些 许问题让高职院校在推进课程思政育人工作陷入困境。主要有各类教师协同 合作、管理机制、课程体系构建等方面。笔者从现有经验的了解中, 初步总 结以下经验。

(一) 加强高职院校协同推进课程思政制度建设, 做好顶层设计

目前, 高职院校更多是通过课程试点来进行思政育人, 暂时没有相关的 法律法规文件, 而且课程思政育人的重要性还没有引起各学校的重视, 只有 法律法规作为规范, 从而让政府、学校、老师重视, 并形成一种主动意识, 而不是被动意识积极参与其中, 这一政策才能落到实处, 达到协同育人的效 果。课程思政协同育人机制是一项系统工程, 需要国家、省、市、区各级政 府行政主导和推动, 各部门通力合作和共同推进。我国从国家和地方层面已 经逐步开始实践 $[4]$ 。但是其中的具体实施落实, 需要各大高校进行探索和制 度完善。加强课程思政改革过程中的部门协同，做好顶层设计便于建构符合 高校自身特色和学生发展特点的教学内容体系架构, 同时明确课程思政改革 工作的基本原则、涉及到的各部门的工作职责分工、具体实施办法, 全面系 统进行改革探索。

(二) 完善教学管理制度, 提升教师参与度。

课程思政协同育人中, 教师作为主体力量不可替代, 要发挥各类子系统 (思政教师、辅导员、专业课教师、企业导师)的主观能动性, 这四者隶属不 同部门, 而且相互独立, 造成了一定的隔离。而且有的专业课教师在推进课 程思政建设过程中主动性不强, 能力不足, 对待课程思政教学认为是附加的 任务, 采取消极的态度等等都是亟待解决的困难。实践证明, 四方力量的协 同育人才能达到最好的效果, 思政育人需要高职院校相关部门和人员的广泛 参与和写作，正是基于对课程思政建设的认识和实践，高职院校通过建设协 同创新平台将思政教师、辅导员、专业课教师、企业导师汇集在一起，对大 学生的思想政治教育工作群策群力, 给予多方参与教育的平台和机会。通过 
提升教师的参与度, 自下而上强化老师对于各类课程思政元素的挖掘和总结, 使教师真正树立起理论知识讲授、职业技能培养和大学生价值引领相结合统 一的教学理念, 强化教师的三全育人意识, 增加教师适度的职业危机感和紧 迫感，在一定程度上帮助教师客服职业倦急并发挥他们的积极主动性和争先 创优意识 [5]。多方教师的互动交流中, 不同学科知识和教学理念的碰撞打破 了之前单一的思政育人风格, 能激发新的教育智慧。教师的深度参与能激发 思政工作热情, 促进其专业的持续活力发展, 同时也为思政教育补充了新鲜 元素, 有利于增强学校人员组织的生命力和创新性。

由此可见, 高职院校需要进行管理体制的改革, 实施定期交流、培训提 升和保障等来激发教师教育热情, 真正做到政策与教师主动相结合。

（三）构建协同育人教学体系，建立评价反馈机制。

高效便捷、多元化的沟通方式是思政教师、辅导员、专业课教师、企业 导师协同育人的保障。首先, 要有目的、有计划、有组织的建立好四方之间 的联系渠道, 互通有无, 适当打通课堂内外思政育人壁垒。线上线下构建出 新场地、多阵地、实际场景的联动, 基于各个学科特点和课程教学实际情况 来有机融合融入思政元素，协同开发课程，扩宽育人途径。首先对于高职院 校, 其育人观念是培养有高素质的高技能技术人才, 这就需要从学校层面加 强课程思政宏观制定和管理, 高职院校和二级学院需要结合学校实际和专业 特色进行课程思政建设和考核评价制度。课程思政育人过程是一个动态的过 程, 是教学资源和教学理念不断融合的动态过程, 是各方力量的协同合作的 过程。这更需要思政教师、辅导员、专业课教师、企业导师以思政育人为目 的加强在理论研究和教学活动等方面的合作, 能够在教学和学生管理过程中 完善教学方法、课程思政元素的挖掘, 同时也让学生的思政课程内容和专业 更为契合, 这些都能使得各类教师和辅导员对学生价值引领和素质培养的效 率更高。

此外, 建立评价反馈机制, 是课程思政协同育人持续改进的重点, 推进 以评促建、以评促改、评建结合来激发效用, 并把四方力量协同育人工作成 果作为考评晋升选拔等重要依据。建立评价, 加强反馈是引导平台建设决策 的依据。

\section{4. 结语}

笔者结合各地高校协同推进课程思政建设的经验, 思考应该如何进行课 程思政改革, 如何转变思政教师、辅导员、专业课教师、企业导师的教学观 念，提高思政教育水平，共同提升协作能力，实现思政育人的目标。在新时 代课程思政改革大背景下, 无论是教师队伍的改革还是实践探索的经验都有 一定的成效，但是相对于协同育人机制的构建还不够成熟，如何思考具体的 保障机制、激励机制和规范机制是当前课程思政协同育人的重难点。本文的 创新之处在于研究内容的创新, 在研究分析课程思政建设过程中的实践案例 的基础上，探讨如何使得思政教师、辅导员、专业课教师、企业导师进行协 作来达到课程思政育人效果的最优化。笔者认为各个高职院校在贯彻落实课 程思政的同时能结合学校实际特色进行创新, 不断丰富课程思政改革内涵, 
这不仅仅是理论研究的需要, 同时也是促进高职院校推荐课程思政协同育人 的现实需求。

\section{基金项目}

四川邮电职业技术学院一般课题《高职院校多方协同推进课程思政育人 的实践与探索》(YDXJKY202060)阶段性成果。

\section{Conflicts of Interest}

The authors declare no conflicts of interest.

\section{References}

[1] 陈奎宁. “新三论”的启示一一谈耗散结构论、协同论和突变论 [J]. 科技导报, 1987(1): 40-42.

[2] 中共中央、国务院印发《关于加强和改进新形势下高校思想政治工作的意见》 [J]. 云南教育(视界时政版), 2017(3): 2 .

[3] 王海威, 王伯承. 论高校课程思政的核心要义与实践路径 [J]. 学校党建与思想教 育, 2018(14): 32-34.

[4] 陈宏. 高职院校专业课“课程思政”实践探讨 [J]. 航海教育研究, 2019, 36(4): 85-87.

[5] 马亮, 顾晓英, 李伟. 协同育人视角下专业教师开展课程思政建设的实践与思考 [J]. 黑龙江高教研究, 2019(1): 125-128.

\section{Appendix (Abstract and Keywords in Chinese) 高职院校协同推进课程思政建设的实践与探索}

摘要：目前，高职院校课程思政协同育人建设过程中初步取得一定的有效探 索和实践成效，但是还有些许问题让高职院校在推进课程思政育人工作陷入 困境。主要有各类教师协同合作、管理机制、课程体系构建等方面。所以如 何在制度建设、队伍培养和教书育人体系等方面进行探索是推进协同思政育 人工作实效的重要保障。此外，构建新时代课程思政协同育人机制实现多方 协同发展模式，对于形成 “三全育人” 和 “大思政” 格局起关键作用。

关键词：高职院校，课程思政，实践探索 